\title{
Saliva Tgf $\beta 1$ Level in Patients with Type 2 Diabetes Mellitus and Primary Hypertension on Dental Caries
}

Masriadi - ( $\nabla$ arimasriadi@gmail.com )

Universitas Muslim Indonesia

Hasta Handayani Idrus

Universitas Muslim Indonesia

\section{Risnayanti Anas}

Universitas Muslim Indonesia

Muhammad Fajrin Wijaya

Universitas Muslim Indonesia

\section{Sari Aldilawati}

Universitas Muslim Indonesia

Helwiah Umniyati

Yarsi University

\section{Tuti Alawiyah}

Universitas Prof Dr Moestopo

Nur Najma Tasyah

Universitas Muslim Indonesia

\section{Research Article}

Keywords: TGF $\beta 1$ levels, Saliva, Type 2 diabetes mellitus, Primary hypertension, Dental caries

Posted Date: February 8th, 2022

DOI: https://doi.org/10.21203/rs.3.rs-1140528/v1

License: (c) (1) This work is licensed under a Creative Commons Attribution 4.0 International License.

Read Full License 


\title{
Saliva Tgf 1 Level in Patients with Type 2 Diabetes Mellitus and Primary Hypertension on Dental Caries
}

\author{
Masriadi $^{*}$, Hasta Handayani Idrus ${ }^{2}$, Risnayanti Anas ${ }^{3}$, Muhammad Fajrin Wijaya ${ }^{4}$, Sari Aldilawati ${ }^{5}$, Helwiah \\ Umniyati $^{6}$, Tuti Alawiyah ${ }^{7}$,Nur Najma Tasyah ${ }^{5}$
}

\begin{abstract}
${ }^{1}$ Department of Epidemiology, Faculty of Public Health, Universitas Muslim Indonesia, Makassar.
${ }^{2}$ Departement of Microbiology, Faculty of Medicine, Universitas Muslim Indonesia, Makassar.

${ }^{3}$ Departemen of Oral Biology, Faculty of Dentistry, Universitas Muslim Indonesia, Makassar.

${ }^{4}$ Departemen of Oral Surgery \& Maxillofacial, Faculty of Dentistry, Universitas Muslim Indonesia, Makassar.

${ }^{5}$ Departemen of Dental Public Health, Faculty of Dentistry, Universitas Muslim Indonesia, Makassar.

${ }^{6}$ YARSI University, Departemen of Dental Public Health, Jakarta, Indonesia

${ }^{7}$ Departement of Dental Material, Faculty of Dentistry, Prof. Dr. Moestopo Beragama, University, Jakarta
\end{abstract}

*Correspondence: Masriadi (arimasriadi@gmail.com)

\begin{abstract}
Background: The purpose of this study is to analyze the relationship and differences in salivary Tgf $\beta 1$ levels in patients with type 2 diabetes mellitus (T2DM) and primary hypertension (PH) with dental caries patients.

Methods: The research design used is a clinical experimental approach. Salivary examination of T2DM and $\mathrm{PH}$ patients was carried out by laboratory staff at the Matakali Health Center and assisted by the research team, then continued with the examination of TGF $\beta 1$ levels at the microbiology laboratory of Hasanuddin University, Indonesia, which became a research partner. Saliva TGF $\beta 1$ levels were measured with a commercial Human TGF $\beta 1$ kit ELISA Assaygenie. Sampling using purposive sampling technique. Test analysis with Chi Square and independent sample T-test. The sample size in this study was 60 samples, namely 30 T2DM patients, $30 \mathrm{PH}$ patients aged 18-40 years. Analysis is Chi Square and independent T-test.

Results: The results of this study when viewed from the distribution of tooth brushing habits in T2DM patients, namely the frequency of brushing teeth is not good ( $1 \mathrm{x}$ a day) and dental caries is $56.7 \%$, while $\mathrm{PH}$ patients are $63.4 \%$. This shows that the frequency of tooth brushing affects the occurrence of dental caries in T2DM and PH patients. Likewise, when viewed from the sex distribution of TD2M in males $60 \%$ and females the lowest $40 \%$. Gender distribution in patients with $\mathrm{PH} \&$ dental caries with the largest proportion of male $53.3 \%$ and the lowest female $46.7 \%$. Salivary TGF $\beta 1$ levels of patients with T2DM \& Caries, PH with dental caries were $577.85 \mathrm{pg} / \mathrm{ml}(0.042)$ and $386.3894 \mathrm{pg} / \mathrm{ml}(0.024)$. Then continued with testing the effect of TGF $\beta 1$ on T2DM and $\mathrm{PH}$ patients with dental caries, namely T2DM patients (p. 0.042) and PH patients (p. 0.024). This shows that there is a significant effect between salivary TGF $\beta 1$ levels of T2DM and PH patients on dental caries. Likewise, it was found that there was a significant difference between T2DM and PH in dental caries by looking at the average value of salivary TGF $\beta 1$ on PH was $386,3894 \mathrm{pg} / \mathrm{mL}$ while salivary TGF $\beta 1$ on T2D was $577,8546 \mathrm{pg} / \mathrm{mL}$. It can also be seen from the standard deviation value of T2DM deviation is 173.04621, while HTP is 95.93092. Conclusion: There is associated and difference of Salivary TGF $\beta 1$ levels of patients with T2DM and $\mathrm{PH}$ at the age of 18-40 years with dental caries. The higher the salivary TGF $\beta 1$ level, the higher the risk of dental caries.
\end{abstract}

Keywords: TGF $\beta 1$ levels, Saliva, Type 2 diabetes mellitus, Primary hypertension, Dental caries 
Background Diabetes mellitus (DM) is a disease that has multiple risk factors that are important in the development of cardiovascular disease. Therefore, diabetes mellitus has a relationship with hypertension ${ }^{[1]}$ Diabetes mellitus can cause dysfunction in various cells and different tissues, including tissues in the oral cavity such as the salivary glands. Decreased salivary flow rate can also occur in patients with poorly controlled glycemia. The high risk of DM in the oral cavity, causing oral injury, decreased speed and quality of wound healing. ${ }^{[2-3]}$ In addition, a history of hypertension, xerostomia has an important role in increasing the risk of dental caries. ${ }^{[4]}$ Dental caries results from the demineralization process which causes damage to the hard tooth tissue. Diabetes mellitus is one of the predisposing factors that affect the occurrence of dental caries due to uncontrolled blood glucose levels causing high levels of glucose in saliva. ${ }^{[5]}$ Likewise, hypertension is a degenerative and the sufferer must take antihypertensive drugs. Antihypertensive drugs have systemic side effects and effects on the oral cavity, one of which is to reduce the amount of salivary flow so to facilitate the occurrence of dental caries. ${ }^{[6]}$

Growth factor betal (TGF $\beta 1$ ) has a close relationship in the physiopathogenesis of dysregulated hypertension in patients with diabetes mellitus. ${ }^{[7-8]}$ In the process of embryogenesis, salivary glands, TGF $\beta 1$ expression is responsible for disruption of one of the glandular branches in the oral cavity and has an important role in regulating the proliferation and differentiation of epithelial cells. This can affect the homeostatic process in the oral mucosa. ${ }^{[9]}$ This has been proven in studies using experimental animals suffering from diabetes mellitus. The results explained that in these animals, the production of TGF $\beta$ isoforms in the salivary glands was impaired. ${ }^{[10]}$ Diabetes is diagnosed by testing the level of sugar or glycated hemoglobin in the blood. T2DM, also known as adult-onset diabetes, is characterized by high blood pressure, insulin resistance, and insulin deficiency. ${ }^{[1]}$

Transforming growth factor beta1 (TGF $\beta 1$ ) has been implicated in the physio pathogenesis of hypertension and has also been reported to be dysregulated in diabetic patients ${ }^{[10-11]}$ During salivary gland embryogenesis, TGF $\beta 1$ expression is responsible for glandular branch disorders and has an important role in regulating epithelial cell proliferation and differentiation, affect oral mucosa homeostasis. In animal models that diabetes affects the production of TGF isoforms in the salivary glands so that it can be used as a basis for direct testing in humans. ${ }^{[12]}$

There is a possible relationship between T2DM and PH with a decrease in the amount and quality of saliva. Impaired salivation can reflect changes in the oral tissues that cause dental caries. Based on this background, the researcher wanted to know the association and difference of Saliva TGF $\beta 1$ Level in patients T2DM and PH with dental caries.

\section{Methods}

The research design used is a clical experimental approach. The population of the study was the community at the Matakali Health Center, Polewali Mandar Regency, who were patients with T2DM and PH and experienced dental caries aged 18-40 years. Inclusion criteria were T2DM patients who had HbAlc examination at the partner hospital of the Matakali Health Center, PH patients (grade 1), had dental caries, aged 18-40 years, did not smoke, recommended a sugar diet and reduced consumption of cariogenic foods 7 days before sampling saliva. The exclusion criteria were that the patient had a history of TB and HIV and diseases manifested in the oral cavity. The sample size is 60 people, namely $30 \mathrm{~T} 2 \mathrm{DM}$ patients, $30 \mathrm{PH}$ patients. The exclusion criteria were that the patient had a history of TB and HIV disease and the disease manifested in the oral cavity. The sample size is 60 people, namely $30 \mathrm{~T} 2 \mathrm{DM}$ patients, $30 \mathrm{PH}$ patients.

Salivary examination of T2DM and PH patients was carried out by laboratory staff at the Matakali Health Center and assisted by the research team, then continued with the examination of TGF $\beta 1$ levels at the microbiology laboratory of Hasanuddin University, Indonesia, which became a research partner. Saliva TGF $\beta 1$ levels were measured with a commercial Human TGF $\beta 1$ ELISA Kit 
(MyBio Source). Sampling using purposive sampling technique. Test analysis with Chi Square and independent sample T-test.

\section{Results}

The results of this study when viewed from table 1, the distribution of tooth brushing habits in T2DM patients, namely the frequency of brushing teeth is not good ( $1 \mathrm{x}$ a day) and dental caries is $56.7 \%$, while $\mathrm{PH}$ patients are $63.4 \%$. This shows table 2 , that the frequency of tooth brushing affects the occurrence of dental caries in T2DM and PH patients. Likewise, when viewed from the sex distribution of TD2M in males $60 \%$ and females the lowest $40 \%$. Gender distribution in patients with $\mathrm{PH} \&$ dental caries with the largest proportion of male $53.3 \%$ and the lowest female $46.7 \%$.

Salivary TGF $\beta 1$ levels of patients with T2DM \& Caries this shows table 3, PH with dental caries were $577.85 \mathrm{pg} / \mathrm{ml}(0.042)$ and $386.3894 \mathrm{pg} / \mathrm{ml}(0.024)$. Then continued with testing the effect of TGF $\beta 1$ on T2DM and PH patients with dental caries table 4, namely T2DM patients (p. 0.042) and PH patients (p. 0.024). This shows that there is a significant effect between salivary TGF $\beta 1$ levels of T2DM and PH patients on dental caries. Likewise, it was found that there was a significant difference between T2DM and PH in dental caries by looking table 5, the average value of salivary TGF $\beta 1$ on PH was $386,3894 \mathrm{pg} / \mathrm{mL}$ while salivary TGF $\beta 1$ on T2DM was $577,8546 \mathrm{pg} / \mathrm{mL}$. It can also be seen from the standard deviation value of T2DM deviation is 173.04621, while PH is 95.93092 .

Discussion

The sex distribution in T2DM with dental caries is $60 \%$ male and $40 \%$ female. The sex distribution of HTP and experiencing dental caries were $53.3 \%$ male and $46.7 \%$ female. The results of this study indicate that men suffer from more T2DM and $\mathrm{PH}$ with high rates of dental caries. However, in this study it was found that T2DM and PH patients who had high caries were higher in male than female. This happens because the number of samples selected is more male.

Further examination was carried out by looking at the salivary TGF $\beta 1$ level in T2DM and PH patients with dental caries. The results showed that the salivary TGF $\beta 1$ level for T2DM patients was considered normal, namely $171,9659 \mathrm{pg} / \mathrm{mL}$. The mean value of TGF $\beta 1$ level in T2DM patients was $577.8546 \mathrm{pg} / \mathrm{mL}$ (p. 0.042) while in PH patients it was $386.3894 \mathrm{pg} / \mathrm{mL}(0.024)$. This indicates that the level of TGF $\beta 11$ in T2DM and PH patients has a significant effect on the occurrence of dental caries.

The increase in salivary TGF $\beta 1$ levels is influenced indirectly by pathophysiological differences in blood glucose homeostatic disturbances and increased blood pressure, especially supported by other factors such as untreated dental caries. Although it is still not known with certainty whether the emergence of this pathology is due to the systemic profile of DM and hypertension or is caused by local manifestations as inferior or salivary flow velocity, changes in the buccal mucosal epithelium or even changes in salivary composition. ${ }^{[13-14]}$

We know that diabetes mellitus is a systemic disease that manifests in the oral cavity. Patients with diabetes mellitus experience an increase in the number of bacteria in the oral cavity, causing abnormalities in the oral cavity. The most prominent complaint of oral conditions in people with diabetes mellitus is a decrease in salivary flow which causes dry mouth (xerostomia) and causes a high frequency of dental caries. Decreased salivary flow can increase salivary glucose and decrease the selfcleansing effect that may contribute to the increased prevalence of dental caries. In T2DM patients with poor oral hygiene, it will trigger plaque accumulation so that the self-cleansing effect of saliva is reduced, plaque is easy to stick causing demineralization and enamel damage so that dental caries is easy to occur. ${ }^{[15]}$

The role of TGF $\beta 1$ in cardiovascular diseases such as hypertension is controversial. TGF $\beta 1$ plays a role in the development of cardiovascular-renal complications based on pathophysiological conditions in humans. Patients suffering from chronic diseases, such as hypertension, diabetes mellitus and hypercholesterolemia can result in end-organ damage (heart dysfunction, arteriosclerosis and chronic kidney failure). This gives a high contribution to the morbidity and mortality rates. Previous studies have shown that TGF $\beta 1$ is an important cause of fibrosis, extracellular matrix accumulation and epithelial/endothelial-mesenchymal transformation. All of these are pathogenic in the development of end-organ damage. ${ }^{[16-18]}$ 
We know that the cause of hypertension is not only a decrease in organ function which is characterized by a decrease in arterial elasticity and blood vessel stiffness but can also be caused by multifactorial causes such as stroke, heart failure, chronic kidney disease, and visual impairment. ${ }^{[19-22]}$ Several studies suggest that the role of TGF $\beta 1$ may protect or even lead to the development of this cardiovascular disease. This is because TGF $\beta 1$ is one of the immunomodulatory cytokines whose work affects many types of cells that make up the walls of heart blood vessels. Transforming growth factor TGF $\beta 1$ can play a role in cell migration, differentiation, proliferation and apoptosis. ${ }^{[23]}$

Djukic et al showed in a population of 387 hypertensive subjects that hypertension combined with diabetes promoted a significant reduction in salivary flow rate depending on the type of antihypertensive drug administered during treatment. Despite a decrease in salivary flow, here only $50 \%$ of patients in the diabetes mellitus group with hypertension reported frequent sensations of dry mouth, while it has been reported that the majority of patients exhibiting this disease association have xerostomia. ${ }^{[24]}$

People with diabetes and hypertension usually experience impaired wound healing. This condition may be caused by changes in the cytokine profile in saliva. The cell motility proteins involved are expressed in the saliva of patients with DM. Salivary TGF $\beta 1$ levels are higher when diabetes is associated with hypertension as indicated by the positive correlation between the presence of growth factors in saliva and fasting plasma glucose concentrations in the blood. ${ }^{[25-26]}$

TGF $\beta 1$ plays a role during the physiological development of glands involved in the proliferation and differentiation of epithelial cells and is one of the molecules responsible for the epithelial-mesenchymal cell transition in the pathological process of oral cancer formation. These results indicate that the oral effects induced by T2DM and $\mathrm{PH}$ are not associated with changes in epithelial cell proliferation, but other studies have described the involvement of other cells that may be a possible factor for oral carcinogenesis. Burzlaff et al observed that the most common cell types in the healthy oral mucosa were intermediate and superficial. Other studies have investigated the effect of type 2 diabetes mellitus on oral cells associated with cell maturation patterns. [27]

\section{Conclusions}

Based on the results of research on salivary TGF $\beta 1$ levels between type 2 diabetes mellitus (T2DM) and primary hypertension $(\mathrm{PH})$ at the age of $18-40$ years, it can be concluded that there is a very significant effect of salivary TGF $\beta 1$ levels in patients with type 2 diabetes mellitus and primary hypertension on dental caries. One of the limitations of this study is that several risk factors for dental caries cannot be controlled, such as oral hygiene, bacterial factors that cause dental caries.

\section{Authors' contributions}

Masriadi has full access to all data in this study and is responsible for the integrity of the data and the accuracy of the data analysis. Concept and design: Masriadi. National and institutional policies: Masriadi, Hasta Handayani, Risnayanti Anas. Laboratory support: Hasta Handayani Idrus, Nur Najma Tasyah and Tuti Alawiyah. Data acquisition, analysis, or interpretation: Muh Fajrin Wijaya, Sari Aldilawati, and Helwiah Umniyati

Funding

Nil.

\section{Availability of data and materials}

The database used to extract data from individual studies and the code associated with the table design cannot be uploaded to a public repository because the data provider (at the Matakali Health Center Ingredient) does not enter it because it is very confidential. Research data can be obtained by contacting the Chairperson in charge of Non-Communicable Diseases at the Matakali Health Center, Polewali Mandar Regency, South Sulawesi, Indonesia.

\section{Declarations}

Ethical policy and institutional review board statement 
All procedures were carried out according to the ELISA examination method. Ethical clearance from the Institutional Committee Universitas Muslim Indonesia (No.5271/A/KEPK-UMI/III/2021) was obtained prior to the start of the study. National guidelines followed in accordance with the Declaration of Helsinki

\section{Consent for publication}

Not applicable

\section{Competing interest}

The authors declare they have no competing interest

\section{Patient declaration of consent}

Informed consent (written and oral) was obtained from all the parents and participants.

\section{Acknowledgments}

The authors thank Calvin M. Kunin for his thoughtful thoughts on improving the manuscript. Hasta Handayani has received funding from the Matakali Health Center, Polewali Mandar Regency. The funding source had no role in the design and conduct of the study, data collection, analysis or interpretation, writing of the manuscript, or the decision to submit it for publication.

\section{References}

1. Sahakyan K, Klein BE, Myers CE, Tsai MY, Klein R. Novel Risk Factors in Long-Term Hypertension Incidence in Type 1 Diabetes Mellitus. Am Heart J 2010;159(6):1074-1080.

2. Deshpande K, Jain A, Sharma R, Prashar S, Jain R. Diabetes and Periodontitis. J Indian Soc Periodontol 2010;14(4):207-212.

3. Rojo-Botello NR, Garcia-Hernandez AL, Moreno-Fierros L. Expression of Toll-Like Receptors 2, 4 and 9 is Increased in Gingival Tissue from Patients with Type 2 Diabetes and Chronic Periodontitis. J Periodontal Res 2012;47(1):62-73.

4. Sreebny LM, Schwartz SS. A Reference Guide to Drugs and Dry Mouth-2nd Edition. Gerodontology1997;14(1):33-47.

5. Al-Maskari, AY, Al-Maskari MY, Salem A. Oral Manifestation and Complications of Diabetes Mellitus: A review Sultan Qaboos Unive Med J. 2011; 11(2): 179-86.

6. Annisa Vanya Mokoginta, Michael A. Leman, Damayanti H.C. Assessment of The Risk of Dental Caries in Users of Amlodipine Antihypertensive Drugs Based on Salivary Flow Rate. Pharmacon The Scientific J of Pharmacy. 2016; 5(1): 103-108

7. Derhaschnig U, Shehata M, Herkner H, Bur A, Woisetschlager C, Laggner AN, et al. Increased Levels of Transforming Growth Factor-Betal in Essential Hypertension. Am J Hypertens 2002;15(3):207-11.

8. Yadav H, Quijano C, Kamaraju AK, Gavrilova O, Malek R, Chen W, et al. Protection from Obesity and Diabetes by Blockade of TGF- $\beta /$ Smad 3 Signaling. Cell Metab 2011;14(1):67-79.

9. Lisiane B, Bárbara CS, Nicole CS, Fernanda V, at. al. Effects of Diabetes and Hypertensionon Oral Mucosa and TGF $\beta 1$ SalivaryLevels. Brazilian Dental J 2018; 29(3):309-315

10. Lamers ML, Gimenes FA, Nogueira FN, Nicolau J, Gama P, Santos MF. Chronic Hyperglycaemia Increases TGF- Beta 2 Signaling and The Expression of Extracellular Matrix Proteins in The Rat Parotid Gland. Matrix Biol 2007;26(7):572-582.

11. Adashi EY, Reshick CE. Antagonistic Interactions of Transforming Growth Factors in The Regulation of Granulosa Cell Differentiation. Endocrinology 1986;119(4):1879-81. 
12. Loh H. Periodontal Disease. The Sixth Complication of Diabetes Mellitus. Diabetes Care 1993;16(1):329-334.

13. Derhaschnig U, Shehata M, Herkner H, Bur A, Woisetschlager C, Laggner AN, et al. Increased Levels of Transforming Growth Factor-Betal in Essential Hypertension. Am J Hypertens 2002;15(3):207-11.

14. Lourenco SV, Uyekita SH, Lima DM, Soares FA. Developing Human Minor Salivary Glands: Morphological Parallel Relation between The Expression of TGF-beta Isoforms and Cytoskeletal Markers of Glandular Maturation. Virchows Arch 2008;452(4):427-34.

15. Rao PV, Reddy AP, Lu X, Dasari S, Krishnaprasad A, Biggs E, et al. Proteomic identification of salivary biomarkers of type-2 diabetes. J Proteome Res, 2009;8(1):239-45.

16. Akhurst RJ, Hata A. Targeting the TGF Beta Signalling Pathway in Disease. Nat Rev Drug Discov 2012;11(10):790-811.

17. 14. Zeisberg M, Hanai J, Sugimoto H, et al. BMP-7 Counteracts TGF-Beta1 Induced Epithelial to Mesenchymal Transition and Reverses Chronic Renal Injury. Nat Med. 2003;9(7):964-8.

18. Wylie-Sears J, Levine RA, Bischoff J. Losartan inhibits endothelial-to-mesenchymal transformation in mitral valve endothelial cells by blocking transforming growth factor-betainduced phosphorylation of ERK. Biochem Biophys Res Commun 2014;446(4):870-5.

19. Masriadi, Febrianto Arif. Effectiveness of ergonomic gymnastics on decreasing blood pressure in patients with stage one hypertension, Indonesia. Indian Journal of Forensic Medicine \& Toxicology, 2018; 12(3): 280-284

20. Masriadi, Muhammad Samsul Arifin, Rahmawati Azis. Effect of supervisory drink drugs (SDG) on decreasing blood pressure reduction in hypertension patients, Indonesia. Indian Journal of Forensic Medicine \& Toxicology, 2019; 13(3): 385-390

21. Masriadi, Sumantri Eha. Effectiveness of Foot Soak Therapy with Warm Water on Decreasing Blood Pressure in Patients with Stage One Hypertension, Indonesia. Indian Journal of Forensic Medicine \& Toxicology, 2019; 13(3): 291-296.

22. Masriadi, Sarafin A, Kurniaty P, Chusnul C, Sri D. The Relationship between Dental Care Perception Towardoral Health of Patients with Primary Hypertension in Padongko Health Center, Barru Regency. Medico-legal Update, 2021; 21(2):286-291

23. Lee KY, Bae SC. TGF-beta-dependent cell growth arrest and apoptosis. J Biochem Mol Biol, 2012;35(1):47-53.

24. Seay, U., Sedding, D., Krick, S., Hecker, M., Seeger, W. and Eickelberg. Transforming Growth Factor- $\beta$-Dependent Growth Inhibition in Primary Vascular Smooth Muscle Cells Is p38Dependent. J Pharmacol Exp Ther, 2005; 315(3):1005-12.

25. Djukic LJ, Roganovic J, Brajovic MD, Bokonjic D, Stojic D. The effects of anti-hypertensives and type 2 diabetes on salivary flow and total antioxidant capacity. Oral Dis, 2015;21(15):619625 .

26. Dodds MW, Yeh CK, Johnson DA. Salivary alterations in type 2 (non-insulin-dependent) diabetes mellitus and hypertension. Community Dent Oral Epidemiol, 2010;28(5):373-81.

27. Lee KY, Bae SC. TGF-beta-dependent cell growth arrest and apoptosis. J Biochem Mol Biol, 2012;35(1):47-53. 
Table 1. Toothbrushing habit with dental caries in T2DM and $\mathrm{PH}$

\begin{tabular}{lcrcc}
\hline Toothbrushing & \multicolumn{2}{c}{ T2DM (Dental Caries) } & \multicolumn{2}{c}{ PH (Dental caries) } \\
Frequency & Frequency & Percent & Frequency & Percent \\
\hline Good (2 x a day) & 13 & $43.3 \%$ & 11 & $36.6 \%$ \\
Bad (1x a day) & 17 & $56.7 \%$ & 19 & $63.4 \%$ \\
Total & 30 & $100 \%$ & 30 & $100 \%$ \\
\hline
\end{tabular}

Table 2. Criteria for samples of T2DM and PH patients with dental caries

\begin{tabular}{llllll}
\multirow{2}{*}{ Criteria } & \multicolumn{2}{l}{ T2DM (Dental Caries) } & \multicolumn{2}{l}{ PH (Dental caries) } \\
\cline { 4 - 6 } & & Frequency & Percent & Frequency & Percent \\
\multirow{2}{*}{ Gender } & Male & 18 & $60 \%$ & 16 & $53.3 \%$ \\
\multirow{2}{*}{ Total } & Female & 12 & $40 \%$ & 14 & $46.7 \%$ \\
\hline
\end{tabular}

Table 3. Salivary TGF $\beta 1$ Level Values

\begin{tabular}{rrlllll}
\hline No. & $\begin{array}{c}\text { T2DM } \\
\text { (Dental } \\
\text { caries) }\end{array}$ & $\begin{array}{l}\text { PH (Dntal } \\
\text { caries) }\end{array}$ & $\begin{array}{c}\text { Mean } \\
\text { T2DM } \\
\text { (Dental } \\
\text { caries) }\end{array}$ & $\begin{array}{c}\text { Mean } \\
\text { PH (Dntal } \\
\text { caries) }\end{array}$ & $\begin{array}{c}\text { p-value } \\
\text { T2DM } \\
\text { (Dental } \\
\text { caries) }\end{array}$ & $\begin{array}{c}\text { p-value } \\
\text { PH (Dntal } \\
\text { caries) }\end{array}$ \\
\hline 1 & 400,7598279 & 297,2079799 & & & \\
2 & 521,2181 & 424,0061611 & & & \\
3 & 766,3612504 & 328,9075252 & & & \\
4 & 635,3364631 & 335,2474342 & & & \\
5 & 922,7456739 & 364,8336765 & & & \\
6 & 557,1442514 & 502,1983728 & & & \\
7 & 808,6273108 & 411,326343 & & & \\
8 & 584,6171906 & 542,3511302 & & & \\
9 & 445,1391913 & 392,3066158 & & & \\
10 & 369,0602826 & 347,9272524 & & & \\
11 & 662,8094024 & 288,7547678 & & & \\
12 & 426,1194641 & 599,4103118 & & & \\
13 & 326,7942222 & 278,1882527 & & & \\
14 & 707,1887658 & 305,6611919 & & & \\
\end{tabular}




\begin{tabular}{rrrllll} 
& 533,8979182 & 377,5134946 & $\begin{array}{l}577.8546 \\
\mathrm{pg} / \mathrm{ml}\end{array}$ & $\begin{array}{l}386.3894 \\
\mathrm{pg} / \mathrm{ml}\end{array}$ & 0.042 & 0.024 \\
15 & 400,7598279 & 297,2079799 & & & \\
17 & 521,2181 & 424,0061611 & & \\
18 & 766,3612504 & 328,9075252 & & \\
19 & 635,3364631 & 335,2474342 & & \\
20 & 922,7456739 & 364,8336765 & & \\
21 & 557,1442514 & 502,1983728 & & \\
22 & 808,6273108 & 411,326343 & & \\
23 & 584,6171906 & 542,3511302 & & \\
24 & 445,1391913 & 392,3066158 & & \\
25 & 369,0602826 & 347,9272524 & \\
26 & 662,8094024 & 288,7547678 & \\
27 & 426,1194641 & 599,4103118 & \\
28 & 326,7942222 & 278,1882527 & & \\
29 & 707,1887658 & 305,6611919 & & \\
30 & 533,8979182 & 377,5134946 & & \\
\hline
\end{tabular}

Table 4. Effect of salivary TGF $\beta 1$ T2DM and PH with dental caries

\begin{tabular}{llll} 
& Frequency & Mean \pm SD & p-value \\
\hline T2DM (Dental caries) & 30 & $57,785 \pm 17,304$ & 0.042 \\
PH (Dental caries) & 30 & $36,638 \pm 95,930$ & 0.024 \\
\hline
\end{tabular}

Table 5. Differences between T2DM, PH and dental caries

\begin{tabular}{llll} 
Patient & Mean \pm SD & Mean Differences & p-value \\
\hline T2DM (Dental caries) & $57,785 \pm 17,304$ & 1.914 & \\
PH (Dental caries) & $36,638 \pm 95,930$ & & 0.001 \\
\hline
\end{tabular}


